\title{
PENGARUH MOTIVASI TEHADAP PRODUKTIVITAS KERJA PEGAWAI PADA DINAS PERDAGANGAN DAN PERINDUSTRIAN KABUPATEN MUSI BANYUASIN
}

\author{
Fery Supriyanto \\ Sekolah Tinggi Ilmu Ekonomi Rahmaniyah Sekayu \\ Email : Supriyantofery71@gmail.com
}

\begin{abstract}
ABSTRAK
Penelitian ini bertujuan untuk mengetahui bagaimana pengaruh motivasi terhadap produktivitas kerja pegawai pada dinas perdagangan dan perindustrian Kabupaten Musi Banyuasin, berdasarkan data primer dan data sekunder yang diperoleh melalui observasi, wawancara dan kuesioner. Populasi dan sampel dalam penelitian ini 94 orang. Metode penelitian menggunakan analisa kuantitatif dan kualitatif, metode analisa kualitatif menggunakan uji validitas, menggunakan uji analisa regresi sederhana, uji analisa korelasi. Jumlah responden penelitian sebanyak 94 responden.Variabel bebas penelitian ini yaitu motivasi dan variabel terikatnya yaitu Produktivitas Kerja Pegawai. Hasil uji statistik untuk pengaruh motivasi terhadap produktivas kerja pegawai didapat nilai $t_{\text {hitung }}$ $(5,698)>t_{\text {tabel }}(1,986$.$) , yang artinya terdapat pengaruh positif antara moti$ dengan produktivitas kerja pegawai.
\end{abstract}

\section{Kata kunci: Motivasi, Produktivitas Kerja}

\section{Latar Belakang Masalah}

Untuk mendapatkan sumber daya manusia yang diharapkan oleh organisasi agar memberikan andil positif terhadap semua kegiatan perusahaan dalam mencapai tujuannya, setiap pegawai diharapkan memiliki motivasi kerja yang tinggi sehingga nantinya dapat merangkai sikap kerja yang baik. Motivasi merupakan hal yang sangat penting untuk diperhatikan oleh pihak manajemen bila mereka menginginkan setiap pegawai dapat memberikan kontribusi positif terhadap pencapaian tujuan perusahaan. Karena dengan motivasi, seorang pegawai akan memiliki semangat yang tinggi dalam melaksanakan tugas yang dibebankan kepadanya.

Mengingat pentingnya tuntutan produktivitas pegawai dalam suatu organisasi, motivasi kerja juga harus menjadi perhatian pengelola organisasi. Suwatno (2011: 100), yang mengemukakan bahwa orang mau bekerja untuk memenuhi kebutuhan, baik kebutuhan yang disadari maupun kebutuhan/keinginan yang tidak disadari. Demikian juga orang mau bekerja untuk mendapatkan kebutuhan fisik dan mental. Apabila seseorang termotivasi maka mereka akan mengadakan pilihan yang positif untuk melakukan sesuatu karena mereka mengerti karena tindakan ini mempunyai arti bagi mereka sehingga produktivitas kerja akan meningkat.

Nawawi (2010: 108), menyatakan produktivitas kerja lebih ditekankan pada ukuran daya guna dalam melaksanakan pekerjaan, yang menyentuh aspek ketepatan, kecermatan dan sikap terhadap pekerjaan. 
Ketepatan dan kecermatan dihubungkan dengan keterampilan dan keahlian dalam mempergunakan metode atau cara bekerja dan peralatan yang tersedia.

Dinas Perdagangan dan Perindustrian merupakan instansi pemerintah yang salah satu kegiatannya mengurusi kegiatan perdagangan antar daerah dituntut untuk dapat memasarkan komoditas import dan ekspor indonesia khususnya di Daerah Kabupaten Musi Banyuasin dan sekitarnya. Serta kegiatan Perindustria di wilayah Kabupaten Musi Banyuasin misalnya kegiatan pembangunan.

Fenomena yang terjadi pada Dinas Perdagangan dan Perindustrian Kabupaten Musi Banyuasin tentang motivasi kerja masih ada beberapa pegawai yang tidak melaksanakan pekerjaanya sesuai dengan tugas pokok dan fungsinya sehingga produktivitas kerja mereka menurun menyebabkan mereka bekerja tidak terarah dengan baik diakibatkan oleh motivasi yang kurang, hal tersebut terjadi karena ketidakstabilan hubungan antara atasan dan bawahan agar memberikan timbal balik ke intansi, inilah yang menimbulkan produktivitas kerja karyawan yang kurang baik dan berdampak pada aktivitas dinas. Maka dari itu motivasi dalam kegiatan ini sangat berpengaruh untuk memaksimalkan produktivitas kerja pegawai yang baik pada Dinas Perdagangan dan Perindustrian. Dimana kebiasaan dari pegawai atasan dalam melaksanakan pekerjaannya ia melimpahkan pekerjaan tersebut kepada para pegawai yang tidak memahami tugas tersebut. Akibatnya pekerjaan tersebut tidak berjalan sesuai dengan aturan dan sulitnya mencapai tujuan Dinas Perdagangan dan Perindustrian. Untuk itu perlu dilakukan pemberian motivasi tentang tugas pokok masing-masing para karyawan serta tunjukkan sikap kerja yang baik agar para karyawan dapat meniru serta menjadi tauladaan dalam menjalankan tugasnya pada Dinas Perdagangan dan Perindustrian di Sekayu Kabupaten Musi Banyuasin.

Berangkat dari kondisi tersebut, maka dijadikan dasar untuk melaksanakan penelitian tentang kinerja karyawan. Berdasarkan uraian di atas, maka dapat diangkat judul : "Pengaruh Motivasi terhadapPriduktivitas Kerja Pegawai Pada Dinas Perdagangan dan Perindustrian Kabupaten Musi Banyuasin".

\section{Rumusan Masalah}

Berdasarkan uraian latar belakang dan pengamatan langsung dirumuskan masalah penelitian ini adalahapakah adapengaruhmotivasi terhadapproduktivitas kerja pegawai pada dinas perdagangan dan perindustrian Kabupaten Musi Banyuasin?

\section{Tujuan Penelitian}

Sesuai dengan rumusan masalah, maka tujuan penelitian ini untuk mengetahui bagaimana pengaruhmotivasi terhadap produktivitas kerja pegawai pada dinas perdagangan dan perindustrian Kabupaten Musi Banyuasin.

\section{Metodologi Penelitian \\ Jenis dan Sumber Data}

Adapun jenis dan sumber data yang digunakan Penulis pada penelitian ini adalah data primer dan data sekunder. Data primer yang digunakan oleh Penulis pada penelitian ini adalah data dari hasil kuesioner dan wawancara sedangkan data sekunder yang digunakan adalah gambaran umum dan struktur organisasi Dinas Perdagangan dan Perindustrian Kabupaten Musi Banyuasin.

\section{Teknik Pengumpulan Data}

a. Penelitian Lapangan 
1. Observasi

2. Wawancara

3. Kuesioner

b. Studi Pustaka

\section{Instrumen Penelitian}

Instrumen penelitian adalah alat yang digunakan oleh Penulis untuk mengumpulkan data penelitian. Agar data yang diperoleh mempunyai tingkat akurasi dan konsistensi yang tinggi, maka instrumen penelitian yang digunakan harus valid dan reliabel. Suatu instrumen dikatakan valid jika instrumen tersebut mengukur apa yang seharusnya diukur dan dikatakan reliabel jika suatu alat pengukur menunjukkan konsistensi hasil pengukuran dan objektivitas yang tinggi.

Priyatno (2012: 16), menyatakan teknik pengujuan intrumen dalam penelitian adalah sebagai berikut :

\section{Uji Validitas}

Menurut Priyatno (2012:17), uji validitas dilakukan dengan membandingkan nilai $r$ hitung dengan $r$ tabel untuk tingkat signifikansi 5 persen dari degree of freedom $(\mathrm{df})=\mathrm{n}-2$, dalam hal ini $\mathrm{n}$ adalah jumlah sampel. Jika $\mathrm{r}$ hitung $>\mathrm{r}$ tabel maka pertanyaan atau indikator tersebut dinyatakan valid, demikian sebaliknya bila $\mathrm{r}$ hitung $<\mathrm{r}$ tabel maka pertanyaan atauindikator tersebut dinyatakan tidak valid.

\section{Uji Reliabilitas}

Priyatno (2012: 25), menyatakan uji reliabilitas merupakan alat untuk mengukur suatu kuesioner yang merupakan indikator dari variabel atau konstruk. Suatu kuesioner dikatakan reliabel atau handal jika jawaban seseorang terhadap pernyataan adalah konsisten atau stabil dari waktu ke waktu. Pengukuran reliabilitas dilakukan dengan cara one shot atau pengukuran sekali saja dengan alat bantu SPSS uji statistik Cronbach Alpha $(\alpha)$. Untuk pengambilan keputusan uji reabilitas bisa menggunakan batasan 0,6 , menurut Sekaran dalam Priyatno (2012: 25), reabilitas kurang dari 0.6 adalah kurang baik, sedangkan 0.7 dapat diterima dan diatas 0.8 adalah baik.

\section{Populasi dan Sampel}

Dalam penelitian ini yang menjadi populasi adalah seluruh pegawai Dinas Perdagangan dan Perindustrian Kabupaten Musi Banyuasin sebanyak 94 orang pegawai. Dengan demikian sampel dari penelitian ini adalah seluruh pegawai pada Dinas Perdagangan dan Perindustrian di Sekayu sebayak 94 orang.

\section{Teknik Pengelolaan Data}

\section{Editing \\ 2. Coding \\ 3. Tabulating}

\section{Teknik Analisis Data}

Sugiyono (2012: 131), menyatakan teknik analisa data dalam sebuah penelitian terbagi menjadi 2 (dua), yaitu :

1. Analisis Kualitatif

Teknik analisa kualitatif yaitu mengadakan pembahasan dan pengendalian secara deskriptif.

2. Analisis Kuantitatif

Teknik analisa kuantitatif yaitu penganalisaan data yang menggunakan angkaangka berdasarkan perhitungan matematis. 


\section{Analisis Regresi Linier Sederhana}

Analisis ini digunakan untuk mengetahui seberapa besar pengaruh variabel bebas yaitu : motivasi kerja (X) terhadap variabel terikatnya yaitu produktivitas kerja (Y). Sunyoto (2013: 110), menyatakan persamaan regresi linier sederhana adalah sebagai berikut :

$\mathrm{Y}=\mathrm{a}+\mathrm{bX}+\mathrm{e}$

Keterangan :

$\mathrm{Y}=$ Variabel dependen (produktivitas kerja)

$\mathrm{a}=$ Konstanta

$\mathrm{b}=$ Koefisien garis regresi

$\mathrm{X}=$ Motivasi Kerja

\section{Pengujian Hipotesis}

1 Uji Korelasi (R)

Tabel 1.2

Koefisien Korelasi

\begin{tabular}{|c|c|}
\hline Koefisien Korelasi & Kriteria \\
\hline $0,00-0,199$ & Sangat Rendah \\
$0,20-0,399$ & Rendah \\
$0,40-0,599$ & Sedang \\
$0,60-0,799$ & Kuat \\
$0,80-1,000$ & Sangat Kuat \\
\hline
\end{tabular}

Sumber: Sugiyono (2012: 78)

2 Koefisien Determinasi $\left(\mathbf{R}^{2}\right)$

Kuncoro (2008: 220), menyatakan koefesien determinasi mengukur seberapa jauh kemampuan model dalam menerangkan variasi variabel dependennya. Nilai koefesien determinasi adalah antara nol dan satu nilai $\mathrm{R}^{2}$ yang kecil berarti kemampuan variabel-variabel indenpendent dalam menjelaskan variasi variabel dependen sangat terbatas dan nilai yang mendekati satu berarti variabel-variabel independen memberikan hampir semua informasi yang dibutuhkan untuk memprediksi variasi variabel dependentnya.

\section{Uji Signifikasi Pengaruh Parsial (Uji t)}

Uji t digunakan untuk menguji signifikansi hubungan antara variabel $\mathrm{X}$ dan $\mathrm{Y}$, apakah variabel $\mathrm{X}$ (motivasi kerja) benar-benar berpengaruh terhadap variabel Y (produktivitas kerja) secara terpisah atau parsial Priyatno (2009: 61). Hipotesis yang digunakan dalam pengujian ini adalah:

Ho: $\quad$ Motivasi kerja tidak berpengaruh terhadap produktivitas kerja pegawai Dinas Perdagangan dan Perindustrian Kabupaten Musi Banyuasin

Ha: $\quad$ Motivasi kerja tidak berpengaruh terhadap produktivitas kerja pegawai Dinas Perdagangan dan Perindustrian Kabupaten Musi Banyuasin

Dasar pengambilan keputusan Priyatno (2009: 63), adalah dengan menggunakan angka probabilitas signifikansi yaitu :

a. Apabila t hitung $<\mathrm{t}$ tabel, maka Ho diterima dan Ha ditolak.

b. Apabila $t$ hitung $>\mathrm{t}$ tabel, maka Ho diterima dan Ha ditolak. 


\section{Konsep Motivasi Kerja \\ Pengertian Motivasi Kerja}

Mangkunegara (2010: 93), mengemukakan bahwa motivasi didefinisikan sebagai suatu kecenderungan untuk beraktivitas, dimulai dari dorongan dalam diri (drive) dan diakhiri dengan penyesuaian diri. Penyesuaian diri dikatakan untuk memuaskan diri. Motif dapat muncul sebagai akibat dari keinginan untuk memenuhi kebutuhan yang tidak terpuaskan dimana kebutuhan itu muncul sebagai dorongan internal atau dorongan alamiah. Demikian juga orang mau bekerja untuk mendapatkan kebutuhan fisik dan mental. Handoko (2010: 99), menyatakan motivasi sebagai keadaan dalam pribadi seseorang yang mendorong keinginan individu untuk melakukan kegiatan-kegiatan tertentu untuk mencapai tujuan.

\section{Indikator Motivasi Kerja}

Mangkunegara (2010: 98), menyatakan bahwa pada dasarnya motivasi itu dibagi menjadi dua jenis utama yaitu:

1. Motivasi intrinsik

Motivasi yang timbul dari dalam diri seseorang. Motivasi ini sering disebut motivasi murni. Motivasi intrinsik sebagai pemuas kebutuhan / pemenuhan egoistic needs adalah kepuasan yang berhubungan dengan kebebasan orang untuk mengerjakan sesuatu sendiri dan puas karena hasil menyelesaikannya. Kebutuhan ini dijabarkan dalam sub indikator yang meliputi:
a. Semangat kerja
b. Loyalitas kerja
c. Perasaan bangga dengan tercapainya sasaran/ target
d. Kebebasan menyampaikan pendapat dan gagasan
e. Pengembangan potensi dan kemampuan

2. Motivasi ekstrinsik

Motivasi ekstrinsik adalah motivasi yang timbul disebabkan faktor-faktor yang datang dari luar diri seseorang., misalnya kenaikan pangkat, pujian, hadiah dan sebagainya. Motivasi ekstrinsik sebagai pemuas kebutuhan dijabarkan menjadi:

a. Phisycal needs (kebutuhan fisik). Kebutuhan ini menyangkut kebutuhan fisik/biologis seperti makan, minum, perumahan disamping kebutuhan akan rasa aman dalam menikmatinya.

b. Social needs adalah kebutuhan yang terpusatkan karena memperoleh pengakuan, status, dan dihormati dalam pergaulan masyarakat diterima dan disegani. Kebutuhan ini dijabarkan dalam sub indikator: Upah/gaji, Hadiah/bonus, Tunjangan, Suasana kerja yang aman, tentram dan menyenangkan, serta kesejahteraan karyawan

Motivasi bermanfaat bagi manajemen karena motivasi berfungsi sebagai penggerak, pengarah dan pendorong terjadinya kelakuan, tindakan atau perbuatan. Motivasi kerja karyawan berperan penting dalam menciptakan produktivitas kerja pegawai. Pegawai yang memiliki motivasi yang baik akan menghasilkan produktivitas kerja yang baik pula.

\section{Jenis-jenis Motivasi}


Ada dua jenis motivasi, yaitu motivasi positif dan motivasi negatif dengan penjelasan sebagai berikut:

1. Motivasi Kerja Positif

2. Motivasi Kerja Negatif

\section{Tujuan Motivasi} berikut:

Menurut Hasibuan (20012:146), tujuan motivasi antara lain sebagai

a. Meningkatkan moral dan kepuasan kerja karyawan

b. Meningkatkan produktifitas kerja karyawan

c. Mempertahankan kestabilan karyawan perusahaan

d. Meningkatkan kedisiplinan karyawan

e. Mengefektifkan pengadaan karyawan

f. Menciptakan suasana dan hubungan kerja yang baik

g. Meningkatkan loyalitas, kreatifitas partisipasi karyawan

h. Meningkatkan tingkat kesejahteraan karyawan

i. Mempertinggi rasa tanggung jawab karyawan terhadap tugas-tugasnya

j. Meningkatkan efisien penggunaan alat-alat dan bahan baku

\section{Fungsi Motivasi}

Menurut Taufik (2010: 54), motivasi mempunyai 3 (tiga) fungsi yaitu:

1. Mendorong manusia untuk berbuat, jadi sebagai penggerak atau motor yang melepaskan energi. Motivasi dalam hal ini merupakan motor penggerak dari setiap kegiatan yang akan kerjakan.

2. Menentukan arah perbuatan, yakni ke arah tujuan yang hendak dicapai. Dengan demikian motivasi dapat memberikan arah dan kegiatan yang harus dikerjakan sesuai dengan rumusan tujuan yang sudah direncanakan sebelumnya.

3. Menyeleksi perbuatan, yakni menentukan perbuatan-perbuatan apa yang harus dikerjakan yang serasi guna mencapai tujuan, dengan menyisihkan perbuatanperbuatan yang tidak bermanfaat bagi tujuan tersebut. Pilihan perbuatan yang sudah ditentukan atau dikerjakan akan memberikan kepercayaan diri yang tinggi karena sudah melakukan proses penyeleksian.

\section{Asas-asas Motivasi}

Menurut Hasibuan (2010: 146), asas-asas motivasi ini mencakup beberapa asas-asas sebagai berikut :

a. Asas mengikutsertakan

b. Asas komunikasi

c. Asas pengakuan

d. Asas wewenang yang didelegasikan

e. Asas perhatian timbal balik

Konsep Produktivitas Kerja

Pengertian Produktivitas Kerja

Nawawi (2010: 108), menyatakan produktivitas kerja lebih ditekankan pada ukuran daya guna dalam melaksanakan pekerjaan, yang menyentuh aspek ketepatan, kecermatan dan sikap terhadap pekerjaan. Ketepatan dan kecermatan dihubungkan dengan keterampilan dan keahlian dalam mempergunakan metode atau cara bekerja dan peralatan yang tersedia.

Simanjuntak (2013: 26), menyatakan produktivitas kerja pegawai mengandung pengertian adanya kemampuan pegawai untuk dapat 
menghasilkan barang atau jasa yang dilandasi sikap mental bahwa hari ini harus lebih baik dari hari kemarin, hari esok harus lebih baik dari hari ini. Sikap kerja yang demikian ini akan tetap melekat dalam diri pegawai yang memiliki produktivitas kerja yang tinggi. Penilaian terhadap produktivitas kerja pegawai dapat diukir melalui pelaksanaan kerja yang relatif baik, sikap kerja, tingkat keahlian dan disiplin kerja. Dan untuk mengukur produktivitas kerja pegawai itu sendiri harus mencakup aspek kuantitas dan kualitas pekerjaannya.

\section{Indikator Produktivitas Kerja}

Siagian (2012: 54), menyatakan bahwa ada beberapa faktor yang dinyatakan sebagai indikator dari produktivitas kerja antara lain:

a. Kualitas pekerjaan

b. Kuantitas pekerjaan

c. Ketepatan waktu

d. Semangat kerja

e. Disiplin kerja

Dalam melaksanakan disiplin kerja, disiplin yang baik dapat diukur dalam wujud:

1. Pimpinan atau pegawai datang dan pulang kantor tepat pada waktu yang ditentukan.

2. Menghasilkan pekerjaan baik kuantitas maupun kualitas yang memuaskan.

3. Melaksanakan tugas penuh dengan semangat.

4. Mematuhi semua peraturan yang ada.

\section{Kerangka Pemikiran}

Berdasarkan uraian latar belakang diatas dan landasan teori yang telah dipaparkan, maka kerangka pemikiran digambarkan secara sederhana sebagai berikut :

1. Motivasi Intrinsik

2. Motivasi Ekstrinsik

Sumber:Mangkunegara (2010: 98)
Produktivitas Kerja (Y)

1. Kualitas kerja

2. Kuantitas kerja

3. Ketepatan waktu

4. Semangat kerja

5. Disipin kerja

Sumber : Siagian (2012: 54)

Gambar 1

Kerangka Pemikiran

\section{Hipotesis}

Ho: Motivasi kerja tidak berpengaruh terhadap produktivitas kerja pada Dinas Perdagangan dan perindustrian Kabupaten Musi Banyuasin.

Ha: Motivasi kerja berpengaruh terhadap produktivitas kerja pada Dinas Perdagangan dan perindustrian Kabupaten Musi Banyuasin.

\section{Hasil Penelitian \\ Karakteristik Responden}


Berdasarkan hasil pengumpulan data yang diperoleh melalui kuesioner yang disebarkan kepada pegawai Dinas Perdagangan dan Perindustrian Kabupaten Musi Banyuasin sebagai responden, maka dapat diketahui karakteristik setiap responden. Karakteristik/identitas responden ini berdasarkan jenis kelamin dan umur responden dan pendidikan.

\section{Jenis Kelamin Responden}

\section{Tabel 4.1}

Karekteristik Responden Berdasarkan Jenis Kelamin

\begin{tabular}{|c|c|c|}
\hline Jenis Kelamin & Jumlah & Persentase (\%) \\
\hline Perempuan & 29 & 30,85 \\
\hline Laki-laki & 65 & 69,15 \\
\hline Total & 94 & 100 \\
\hline
\end{tabular}

\section{Umur Responden}

Tabel 4.2

Karekteristik Responden berdasarkan Umur Responden

\begin{tabular}{|c|c|c|}
\hline Umur & Jumlah & Persentase (\%) \\
\hline $17-22$ & 5 & 5,32 \\
\hline $23-28$ & 53 & 56,38 \\
\hline $29-34$ & 19 & 20,21 \\
\hline$>35$ & 17 & 18,09 \\
\hline Total & 94 & 100 \\
\hline
\end{tabular}

\section{Pendidikan Responden}

Tabel 4.3

Karekteristik Responden berdasarkan Umur Responden

\begin{tabular}{|c|c|c|}
\hline Umur & Jumlah & Persentase (\%) \\
\hline SMA & 4 & 4,26 \\
\hline D1 & 8 & 8,51 \\
\hline D3 & 30 & 31,91 \\
\hline S1 & 45 & 47,87 \\
\hline S2 & 7 & 7,45 \\
\hline Total & 94 & 100 \\
\hline
\end{tabular}

\section{Distribusi Jawaban Responden}

Berdasarkan hasil penelitian yang telah dilakukan terhadap 94 orang responden melalui penyebaran kuesioner. Untuk mendapatkan kecenderungan jawaban responden terhadap jawaban masing-masing variabel akan didasarkan pada rentang skor jawaban sebagaimana pada lampiran.

\section{Distribusi Jawaban Responden Untuk Variabel Motivasi}


Tabel 4.4

Tanggapan Responden Mengenai Motivasi

\begin{tabular}{|c|c|c|c|c|c|c|c|}
\hline \multirow{2}{*}{ No } & \multirow{2}{*}{ Pertayaan } & \multicolumn{5}{|c|}{ Skor } & \multirow{2}{*}{ Jumlah } \\
\hline & & STS & TS & $\mathrm{N}$ & $\mathrm{S}$ & SS & \\
\hline & \multirow{2}{*}{$\begin{array}{l}\text { Pegawai } \\
\text { mendapatkan } \\
\text { kebutuhan } \\
\text { yang layak }\end{array}$} & 0 & 0 & 48 & 22 & 24 & 94 \\
\hline & & $0,00 \%$ & $0,00 \%$ & $51,06 \%$ & $23,40 \%$ & $25,53 \%$ & $00 \%$ \\
\hline \multirow[b]{2}{*}{2} & \multirow{2}{*}{$\begin{array}{l}\text { Pegawai merasa } \\
\text { dengan } \\
\text { bekerja di } \\
\text { Dinas } \\
\text { Perdagangan } \\
\text { dan } \\
\text { Perindustrian } 0 \\
\text { kebutuhan } \\
\text { dasar saya } \\
\text { sudah } \\
\text { terpenuhi }\end{array}$} & . & 0 & 40 & 29 & 25 & 94 \\
\hline & & $0,00 \%$ & $0,00 \%$ & $42,55 \%$ & $30,85 \%$ & $26,60 \%$ & $00 \%$ \\
\hline \multirow{2}{*}{$\beta$} & \multirow{2}{*}{$\begin{array}{c}\text { Pegawai merasa } \\
\text { aman dalam } \\
\text { melakukan } \\
\text { pekerjaan }\end{array}$} & 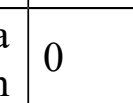 & 0 & 45 & 25 & 24 & 94 \\
\hline & & $0,00 \%$ & $0,00 \%$ & $47,87 \%$ & $26,60 \%$ & $25,53 \%$ & 100 \\
\hline \multirow[b]{2}{*}{4} & \multirow{2}{*}{$\begin{array}{c}\text { Pegawai merasa } \\
\text { tenang dalam } \\
\text { bekerja } \\
\text { karena } \\
\text { tersedianya } \\
\text { jaminan } \\
\text { kesehatan } \\
\text { dari dinas }\end{array}$} & 0 & 0 & 32 & 32 & 30 & 94 \\
\hline & & $0,00 \%$ & $0,00 \%$ & $34,04 \%$ & $34,04 \%$ & $31,91 \%$ & $100 \%$ \\
\hline
\end{tabular}

\begin{tabular}{|c|c|c|c|c|c|c|c|}
\hline \multirow{2}{*}{ yo } & \multirow{2}{*}{ Pertayaan } & \multicolumn{5}{|c|}{ Skor } & \multirow{2}{*}{ Jumlah } \\
\hline & & STS & $\mathrm{TS}$ & $\mathrm{N}$ & $\mathrm{S}$ & SS & \\
\hline \multirow[b]{2}{*}{5} & \multirow{2}{*}{$\begin{array}{l}\text { Pengawai diberi } \\
\text { kesempatan } \\
\text { untuk } \\
\text { mengembang } \\
\text { kan potensD } \\
\text { dan } \\
\text { keterampilan }\end{array}$} & 0 & 0 & 38 & 26 & 30 & 94 \\
\hline & & $00 \%$ & $0.00 \%$ & $40,43 \% 2$ & $27,66 \% 3$ & $1,91 \%$ & $00 \%$ \\
\hline \multirow[t]{2}{*}{$\phi$} & \multirow{2}{*}{$\begin{array}{lr}\text { Pegawai merasa } \\
\text { senang } \\
\text { karena } \\
\text { pegawai di } \\
\text { Dinas } \\
\text { Perdagangan } \\
\end{array}$} & 0 & 0 & 46 & 16 & 32 & 94 \\
\hline & & $00 \%$ & $00 \%$ & $48,94 \%$ & $17,02 \% 3$ & $4,04 \%$ & $00 \%$ \\
\hline
\end{tabular}


Siagian, Sondang P. 2012. Manajemen Sumber Daya Manusia. Jakarta: Bumi Aksara.

Simanjuntak, Payaman, J. 2013. Ekonomi Sumber Daya Manusia. Jakarta: Universitas Indonesia

Sugiyono. 2012. Metode Penelitian Kuantitatif Kualitatif dan R\&D. Bandung: Alfabeta.

Sunyoto, Danang 2013. Metode Penelitian Untuk Bisnis. Yogyakarta: CAPS

Suwatno, Priansa D. 2011. Manajemen SDM dalam Organisasi Publik dan Bisnis. Bandung: Alfabeta

Taufik. 2010. Teori Motivasi dan Pengukurannya. Jakarta: PT. Bumi Aksara.

Zainal, Veithzal Rivai, Mansyur Ramly, Thoby Mutis, Willy Arafah. 2014. Manajemen Sumber Daya Manusia untuk perusahaan dari teori ke praktik. Edisi Ketiga. Jakarta: Rajawali Pers. 